\title{
Enhanching Kharif Groundnut (Arachis hypogaea L.) Yield and Quality in Entisol through Potassic Fertilizer Management
}

\author{
B. Borah*, D.S. Patil and R.B. Pawar \\ Department of Soil Science and Agricultural Chemistry, College of Agriculture \\ (Mahatma Phule Krishi Vidyapith), Kolhapur-416004(M.S.), India \\ *Corresponding author
}

\begin{tabular}{|c|c|}
\hline & A B S T R A C T \\
\hline & $\begin{array}{l}\text { A field experiment was conducted at Post Graduate Research Farm, College of } \\
\text { Agriculture, Kolhapur during kharif season of } 2016 \text { to study the effect of different sources } \\
\text { and levels of potassium (K) on yield and quality of kharif groundnut (Arachis hypogaea } \\
\text { L.) in Entisol. The experiment was laid out in a factorial randomized block design with }\end{array}$ \\
\hline Keywords & $\begin{array}{l}\text { two replications in which treatments comprised of five levels of } \mathrm{K} \text { viz., } 0,10,20,30 \text { and } \\
40 \mathrm{~kg} \mathrm{ha}^{-1} \mathrm{~K}_{2} \mathrm{O} \text { and four sources of } \mathrm{K} \text { viz., muriate of potash (MOP), sulphate of potash }\end{array}$ \\
\hline $\begin{array}{l}\text { Potassium, Fertilizer } \\
\text { source, Groundnut } \\
\text { yield, Oil yield, } \\
\text { Protein content. }\end{array}$ & $\begin{array}{l}\text { (SOP), bagasse ash and schoenite and } 25 \text { and } 50 \mathrm{~kg} \mathrm{ha}^{-1} \mathrm{~N} \text { and } \mathrm{P}_{2} \mathrm{O}_{5} \text {, respectively, was } \\
\text { applied as common basal dose. The results revealed that successive increase in levels of } \\
\text { potassium showed significant effect on yield and yield attributes of groundnut crop, along } \\
\text { with quality. Significantly highest dry pod, kernel and haulm yields }(3169,2213 \text {, and } 3894\end{array}$ \\
\hline Article Info & $\mathrm{kg} \mathrm{ha}^{-1}$, respectively) were recorded by application of $40 \mathrm{~kg} \mathrm{ha}^{-1} \mathrm{~K}_{2} \mathrm{O}$, and among the \\
\hline $\begin{array}{l}\text { Accepted: } \\
\text { 28 September } 2017 \\
\text { Available Online: } \\
10 \text { November } 2017\end{array}$ & $\begin{array}{l}\text { recorded with SOP which were at par with MOP and Schoenite. Significantly highest oil } \\
\text { yield was recorded by application of } 40 \mathrm{~kg} / \mathrm{ha} \mathrm{K}_{2} \mathrm{O}(1053.7 \mathrm{~kg} / \mathrm{ha}) \text { and SOP }(914.55 \mathrm{~kg} \\
\left.\mathrm{ha}^{-1}\right) \text { among the levels and sources of } \mathrm{K} \text {, respectively while interactions were non- } \\
\text { significant. Protein content of groundnut kernel was increased from } 22 \%-24.5 \% \text { with }\end{array}$ \\
\hline & $\begin{array}{l}\text { application of } 40 \mathrm{~kg} \mathrm{~K}_{2} \mathrm{O} \mathrm{ha}^{-1} \text { over control and among sources significantly highest protein } \\
\text { content was reported with MOP }(24.47 \%) \text { which was superior over all other sources of } \\
\text { potassium. The shelling percentage ranged } 67-70 \% \text { but the effect of various treatments on } \\
\text { shelling percentage was non-significant. }\end{array}$ \\
\hline
\end{tabular}

\section{Introduction}

Potassium is one of the 3 main pillers of balanced fertilizer use, along with nitrogen $(\mathrm{N})$ and phosphorus $(\mathrm{P})$. Groundnut is a heavy feeder of potassium and an adequate supply of this nutrient is indispensable to harvest a good crop of groundnut. Potassium plays a vital role in maintaining balance in enzymatic, stomatal activity (water use), transport of sugars, water and nutrient and synthesis of protein, photosynthesis and starch thus $\mathrm{K}$ application increases growth and yield attributes in groundnut (Krauss and Jiyun 2000; Rathore et al., 2014). Out of large percentage of area in India, very little or no potassium $(\mathrm{K})$ fertilizers are being applied and therefore it mainly comes from potassium reserves of the soil.

Potassium fertilizers are one commodity for which country depends solely on import. 
Among them for $\mathrm{K}$ fertilizers, mainly muriate of potash (MOP) is completely dependent on import. Every year India has to spend a bulk of foreign exchange for importing potassium fertilizers. The country imported 3797 thousand tons of $\mathrm{K}$ fertilizer during 2014-15 (Department of Fertilizer, GOI, 2016). Among common potassic fertilizers, Sulphate of potash, is mostly favoured by the majority of growers since it's low salt index, nonhygroscopic and chlorine free K-fertilizer in comparison with muriate of potash, but cost expensive. Indigenously, extraction process of sulphate of potash $\left(\mathrm{K}_{2} \mathrm{SO}_{4}\right)$ and schoenite $\left(\mathrm{K}_{2} \mathrm{SO}_{4}, \mathrm{MgSO}_{4}\right)$ from sea bittern was developed by Central Salt and Marine Chemicals Research Institute, Bhavnagar, Gujarat (Rathore et al., 2014) and some private agri-input agencies. Among them, indigenously produced double salts of $\mathrm{K}$, i.e., potassium schoenite (molar mass $415 \mathrm{~g} \mathrm{~mol}^{-1}$ ) have been found to be beneficial on acidic and alluvial soils which provides a readily available supply of Potassium, Magnesium and Sulfur to growing plants in an ideal ratio; although very little work has been reported so far. Therefore, keeping the above facts in background, relative effect of different potassic sources on yield and quality of kharif groundnut were studied in the present investigation.

\section{Materials and Methods}

The field experiment was conducted during the kharif season of 2016-17 at Post Graduate Research Farm, College of Agriculture, Kolhapur $\left(16^{0} 42^{\prime}\right.$ N latitude, $74^{0} 14^{\prime}$ E longitude and $548 \mathrm{~m}$ AMSL) in sandy clay loam soil $(56.70 \%$ sand, $18.70 \%$ silt and $24.60 \%$ clay) containing available $\mathrm{N}$ (150.25 $\left.\mathrm{kg} \mathrm{ha}{ }^{-1}\right)$, and moderately high $\mathrm{P}_{2} \mathrm{O}_{5}(21.37 \mathrm{~kg}$ $\mathrm{ha}^{-1}$ ) and $\mathrm{K}_{2} \mathrm{O}\left(252.75 \mathrm{~kg} \mathrm{ha}^{-1}\right)$ and $10.35 \mathrm{mg}$ $\mathrm{kg}^{-1}$ available $\mathrm{S}$. The status of organic carbon content $(0.45 \%)$ was moderate and moderately calcareous with 4.87 per cent
$\mathrm{CaCO}_{3}$ equivalent. The soil reaction was slightly alkaline ( $\mathrm{pH}$ 7.6) and EC was normal $\left(0.27 \mathrm{dS} \mathrm{m} \mathrm{m}^{-1}\right)$. The total rainfall received during the period of field experiment was $1056.50 \mathrm{~mm}$ in 63 rainy days. The relative humidity during the crop period was in the range of 70 to 91 per cent at morning and 48 to 90 per cent at evening. The minimum temperature varied from $10.6^{\circ} \mathrm{C}$ to $21.5^{\circ} \mathrm{C}$, while maximum temperature was in the range of $25.3^{0} \mathrm{C}$ to $31.9^{0} \mathrm{C}$. The evaporation during experimentation ranges between $1.4 \mathrm{~mm}$ to $5.7 \mathrm{~mm}$ per day. The experiment was laid out in the factorial randomized block design. The treatments consisted of five levels of potassium viz.0, 10, 20, 30 and $40 \mathrm{~kg} \mathrm{ha}^{-1}$ which were supplied through four different potassium sources viz muriate of potash, sulphate of potash, bagasse ash and schoenite. Groundnut was sown on 28.06.2016 with a spacing $30 \mathrm{~cm} \times 15 \mathrm{~cm}$. After experimental layout Bagasse ash was applied as per the treatments well in advance before dibbling of groundnut seeds and well mixed in surface soil. All the recommended agronomic practices were adopted. Recommended dose of $\mathrm{N}$ and $\mathrm{P}_{2} \mathrm{O}_{5}\left(25: 50 \mathrm{~kg} \mathrm{ha}^{-1}\right)$ was applied to all treatments through Urea and Single super phosphate. Oil content was determined by Soxhlet Ether Extract method (A.O.A.C.2002)

\section{Results and Discussion}

\section{Effect on dry pod, kernel and haulm yield of groundnut}

The yield of dry pod, kernel and haulm of groundnut were increased significantly with increasing levels of potassium and highest yields $\left(31.69,22.13\right.$, and $38.94 \mathrm{q} \mathrm{ha}^{-1}$, respectively) were recorded by application of $40 \mathrm{~kg} \mathrm{~K} \mathrm{~K}_{2} \mathrm{O} \mathrm{ha}^{-1}$. Amongst sources highest yields (27.70, 19.26 and $36.64 \mathrm{q} \mathrm{ha}^{-1}$, respectively) were recorded with $\mathrm{S} 2-\mathrm{SOP}$ which were at par with MOP and schoenite 
(Table 2). The highest yield obtained with SOP might be attributed to its sulphur content.

Interaction effects of different levels and sources of potassium were found nonsignificant in relation to dry pod yield. Potassium play vital role in maintaining balance in enzymatic, stomatal activity (water use), transport of sugars, water and nutrients and synthesis of protein, starch and photosynthesis, thus $\mathrm{K}$ application increased growth and yield attributes in groundnut. The results are in close conformity with the observations recorded by Davide et al., (1986), Vinod Kumar et al., (2000), Hadwani and Gundalia (2005) and Veramani and Subrahmaniyan (2011) who also reported response of groundnut to the applied potassium.

\section{Effect on yield attributes of groundnut}

In general, the yield attributes viz., number of filled and unfilled pods and shelling percentage were influenced by different levels and sources of potassium applications. Significantly highest number of filled pods plant $^{-1}$ (38.89) were recorded with application of $40 \mathrm{~kg} \mathrm{~K}_{2} \mathrm{O} \mathrm{ha}^{-1}$ and $\mathrm{S}_{2}$-SOP (37.10) and significantly lowest unfilled pods plant ${ }^{-1}$ were recorded with $\mathrm{L}_{4}-40 \mathrm{~kg} \mathrm{~K}_{2} \mathrm{O}^{-1}{ }^{-1}$ (7.88) and $\mathrm{S}_{2}$-SOP (7.90) (Table 2). However, interaction effects were found non-significant in relation to number of filled and unfilled pods plant ${ }^{-1}$. The results are in close aggrement with the findings reported by Singh and Chaudhari (1996) and Reddy et al., (2011) who also reported superior performance of groundnut to the SOP with increasing levels of potassium.

The shelling percentage was not much more influenced by the different levels and sources of potassium and it was found non-significant. The highest shelling percentage was recorded in $\mathrm{L}_{4}-40 \mathrm{~kg} \mathrm{~K}_{2} \mathrm{O} \mathrm{ha}^{-1}(69.90 \%)$ and among the sources $S_{2}$ MOP was recorded 69.46 per cent which was close proximity with the findings reported by Rathore et al., (2014).

Fig.1 Yield and yield attributes of groundnut as influenced by different potassic sources and levels

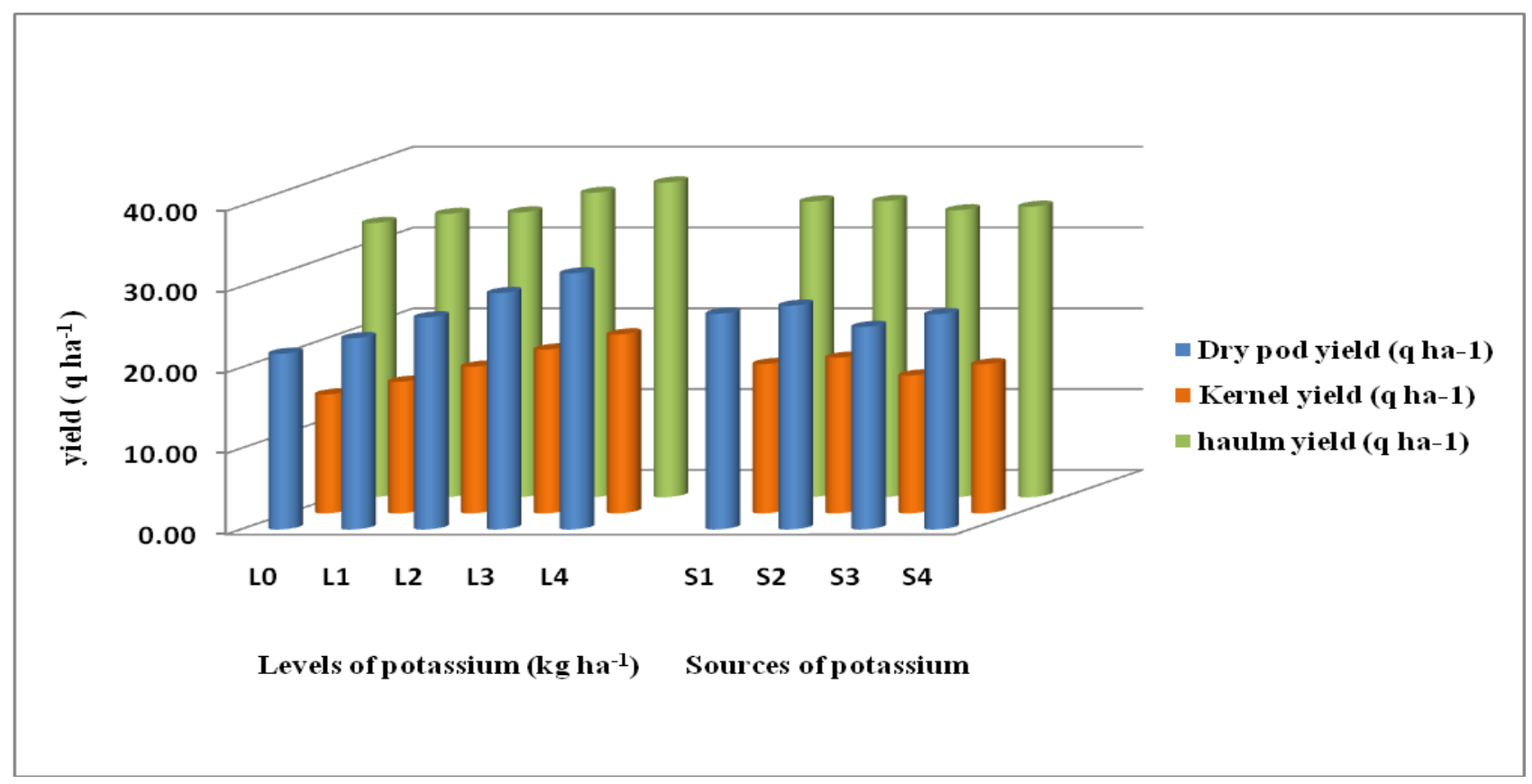


Fig.2 Oil content and protein content of groundnut as influenced by different potassic sources and levels

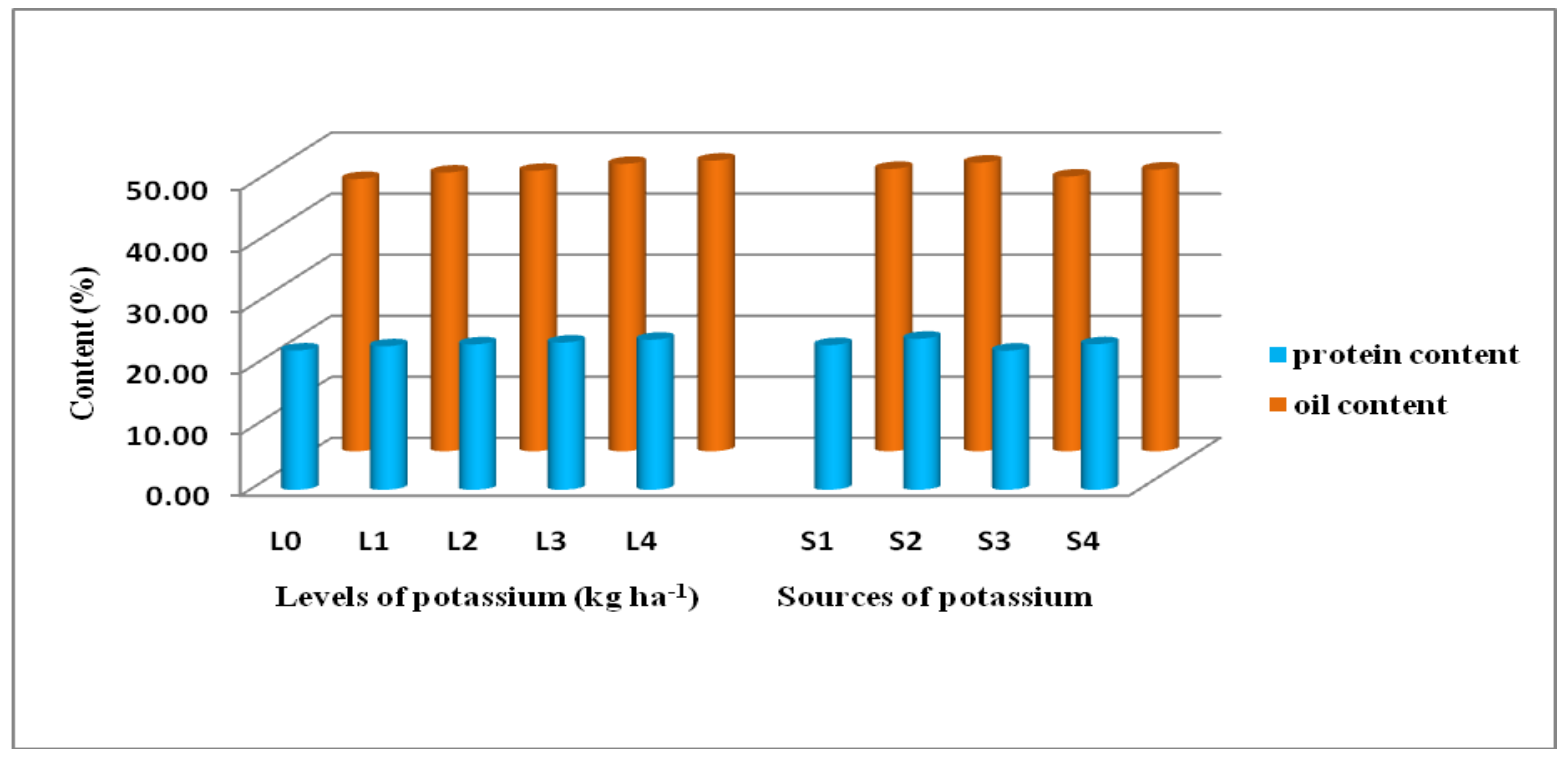

Fig.3 Oil yield of groundnut as influenced by different potassic sources and levels

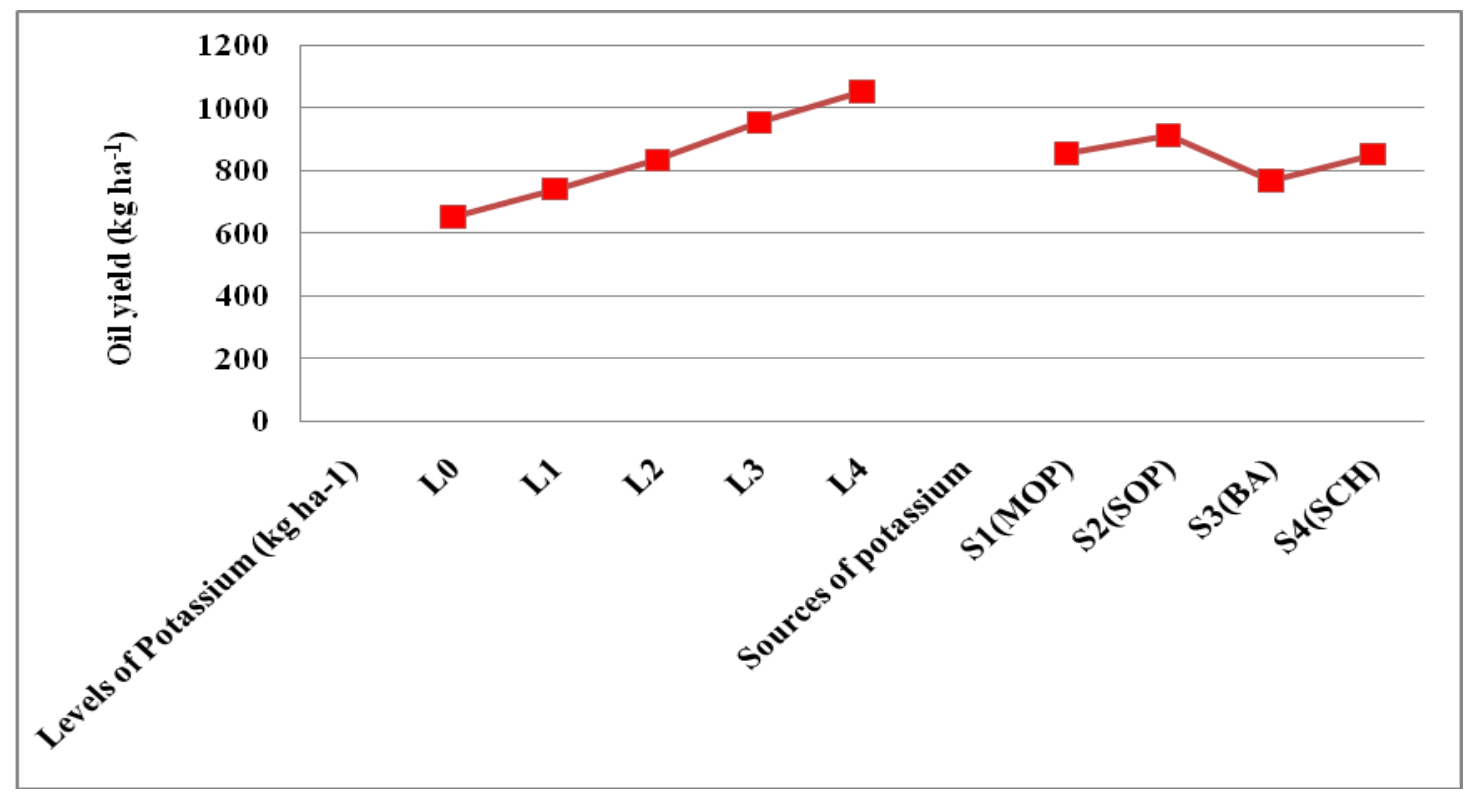

Table.1 Content of potassium $\left(\mathrm{K}_{2} \mathrm{O}\right)$ in different potassium sources

\begin{tabular}{|l|l|}
\hline Sources of Potassium & \multicolumn{1}{|c|}{ Content of $\mathbf{K}_{\mathbf{2}} \mathbf{O}$} \\
\hline Muriate of potash & $60 \%$ \\
\hline Sulphate of potash & $52 \%$ \\
\hline Bagasse ash & $0.02 \%$ \\
\hline Schoenite & $22-24 \%$ \\
\hline
\end{tabular}


Table.2 Yield and yield attributes of groundnut as influenced by different potassic sources and levels

\begin{tabular}{|c|c|c|c|c|c|c|}
\hline Treatments & $\begin{array}{c}\text { Dry pod yield } \\
\left(\mathrm{q} \mathrm{ha}^{-1}\right)\end{array}$ & $\begin{array}{c}\text { Kernel yield } \\
\left(\mathbf{q} \mathbf{h a}^{-1}\right)\end{array}$ & $\begin{array}{c}\text { haulm yield } \\
\left(\mathrm{q} \mathrm{ha} \mathbf{h}^{-1}\right)\end{array}$ & Shelling \% & $\begin{array}{c}\text { Filled pods } \\
\text { Plant }^{-1}\end{array}$ & $\begin{array}{c}\text { Unfilled pods } \\
\text { Plant }^{-1}\end{array}$ \\
\hline \multicolumn{7}{|c|}{ Levels of potassium $\left(\mathrm{kg} \mathrm{ha}^{-1}\right)$} \\
\hline $\mathrm{L}_{0}(0)$ & 21.74 & 14.71 & 33.93 & 67.63 & 24.24 & 9.88 \\
\hline $\mathrm{L}_{1}(10)$ & 23.68 & 16.28 & 35.05 & 68.73 & 29.71 & 9.25 \\
\hline $\mathrm{L}_{2}(20)$ & 26.25 & 18.15 & 35.23 & 69.08 & 33.04 & 8.25 \\
\hline $\mathrm{L}_{3}(30)$ & 29.26 & 20.27 & 37.67 & 69.26 & 36.21 & 8.13 \\
\hline $\mathrm{L}_{4}(40)$ & 31.69 & 22.13 & 38.94 & 69.90 & 38.89 & 7.88 \\
\hline S.E.土 & 0.57 & 0.38 & 0.56 & 0.52 & 1.04 & 0.37 \\
\hline $\mathrm{CD}$ at $5 \%$ & 1.69 & 1.14 & 1.67 & NS & 3.08 & 1.10 \\
\hline \multicolumn{7}{|c|}{ Sources of potassium } \\
\hline $\mathrm{S}_{1}(\mathrm{MOP})$ & 26.69 & 18.48 & 36.58 & 69.19 & 32.79 & 8.60 \\
\hline $\mathrm{S}_{2}(\mathrm{SOP})$ & 27.70 & 19.26 & 36.64 & 69.46 & 37.10 & 7.90 \\
\hline $\mathrm{S}_{3}(\mathrm{BA})$ & 25.07 & 17.06 & 35.49 & 67.89 & 28.77 & 9.40 \\
\hline $\mathrm{S}_{4}(\mathrm{SCH})$ & 26.63 & 18.44 & 35.94 & 69.13 & 31.00 & 8.80 \\
\hline S.E. \pm & 0.51 & 0.34 & 0.50 & 0.47 & 0.93 & 0.33 \\
\hline $\mathrm{CD}$ at $5 \%$ & 1.51 & 1.02 & NS & NS & 2.76 & 0.98 \\
\hline \multicolumn{7}{|c|}{ Interaction (L x S) } \\
\hline S.E.土 & 1.14 & 0.77 & 1.13 & 1.06 & 2.08 & 0.74 \\
\hline $\mathrm{CD}$ at $5 \%$ & NS & NS & NS & NS & NS & NS \\
\hline
\end{tabular}

Table.3 Oil content, oil yield and protein content of groundnut as influenced by different potassic sources and levels

\begin{tabular}{|c|c|c|c|}
\hline Treatments & Oil content $(\%)$ & Oil yield $\left(\mathrm{kg} \mathrm{ha}^{-1}\right)$ & Protein content $(\%)$ \\
\hline \multicolumn{4}{|c|}{ Levels of Potassium $\left(\mathrm{kg} \mathrm{ha}^{-1}\right)$} \\
\hline $\mathrm{L}_{0}$ & 44.58 & 655.16 & 22.82 \\
\hline $\mathrm{L}_{1}$ & 45.64 & 743.69 & 23.51 \\
\hline $\mathrm{L}_{2}$ & 45.92 & 835.45 & 23.83 \\
\hline $\mathrm{L}_{3}$ & 47.06 & 955.29 & 24.12 \\
\hline $\mathrm{L}_{4}$ & 47.59 & 1053.71 & 24.59 \\
\hline S.E. \pm & 0.67 & 21.27 & 0.19 \\
\hline $\mathrm{CD}$ at $5 \%$ & 1.98 & 62.95 & 0.57 \\
\hline \multicolumn{4}{|c|}{ Sources of potassium } \\
\hline $\mathrm{S}_{1}(\mathrm{MOP})$ & 46.24 & 856.90 & 24.74 \\
\hline $\mathrm{S}_{2}(\mathrm{SOP})$ & 47.27 & 914.55 & 23.84 \\
\hline $\mathrm{S}_{3}(\mathrm{BA})$ & 44.99 & 769.13 & 22.79 \\
\hline $\mathrm{S}_{4}(\mathrm{SCH})$ & 46.13 & 854.07 & 23.70 \\
\hline S.E. \pm & 0.60 & 19.02 & 0.17 \\
\hline $\mathrm{CD}$ at $5 \%$ & NS & 56.30 & 0.50 \\
\hline \multicolumn{4}{|c|}{ Interaction ( $\mathrm{L} \times \mathrm{S})$} \\
\hline S.E. \pm & 1.34 & 42.53 & 0.38 \\
\hline $\mathrm{CD}$ at $5 \%$ & NS & NS & NS \\
\hline
\end{tabular}


Effect on oil content, oil yield and protein content of groundnut kernels

The oil content and protein content of groundnut improve significantly with the graded doses of potassium application. Significantly highest $(47.59 \%)$ oil content of groundnut kernel was reported with application of $40 \mathrm{~kg} \mathrm{~K}_{2} \mathrm{O} \mathrm{ha}^{-1}$ but effect of sources and interactions were found nonsignificant whereas this value was highest for SOP (47.27). The results indicated that, significantly highest oil yield $(1053.71 \mathrm{~kg}$ $\left.\mathrm{ha}^{-1}\right)$ was recorded by application of $\mathrm{L}_{4}(40 \mathrm{~kg}$ $\mathrm{K}_{2} \mathrm{O}$ ha $^{-1}$ ) which was significantly superior over rest of $\mathrm{K}_{2} \mathrm{O}$ levels. Among sources $\mathrm{S}_{2}$ (SOP) recorded significantly highest oil yield $\left(914.55 \mathrm{~kg} \mathrm{ha}^{-1}\right)$ than the rest of $\mathrm{K}_{2} \mathrm{O}$ sources. However, the interaction effects were found non- significant in relation to oil yield (Table 3). Balanced use of nutrients might have improved the yield attributing characteristics like root and plant growth, nutrient uptake, physical, chemical and biological activities which ultimately results in higher kernel and oil yield. Increased oil content in SOP was due to the reason that, sulphur might be associated with accelerated formation of acetyl Co- A, a precursor of fatty acids synthesis and enzyme activities of potassium. Umar et al., (1999) and Rathore et al., (2014) have reported similar findings in relation to oil content and oil yield of groundnut.

Protein content of groundnut kernel showed significant response to added potassium and it was increased from 22\%-24.5\% with application of $40 \mathrm{~kg} \mathrm{~K}_{2} \mathrm{O} \mathrm{ha}^{-1}$ over control and $24.74 \%$ protein content was reported with the source MOP which is superior over all other sources of potassium applied in the investigation. Potassium facilitates the uptake as well as assimilation of nitrogen into simple amino acids and amides and, therefore enhanced peptide synthesis which ultimately contributes to improve protein synthesis.
Similar results were also obtained by Umar and Moinuddin (2002) and Veeramani and Subrahmaniyan (2011).

The result from the present study revealed that, significantly highest pod and kernel yield of groundnut were recorded with increasing levels of potassium i.e. $40 \mathrm{~kg} \mathrm{~K}_{2} \mathrm{O}$ ha $^{-1}$ while among the potassium sources, sulphate of potash was significantly superior over bagasse ash and at par with MOP and schoenite. Highest oil yield and protein content were recorded with SOP and MOP both @ $40 \mathrm{~kg}$ $\mathrm{K}_{2} \mathrm{O} \mathrm{ha}^{-1}$, respectively which were significantly superior over bagasse ash. Low solubility rate of bagasse ash might be the probable reason for lower yield and quality of groundnut compared to other sources.

\section{References}

A.O.A.C. 2002. Official Methods of Analysis Association of Official Agricultural Chemists Washington, D.C.

Davide, J.G., Nabhan, H., Tahir Saleem, M. and Nisar Ahmad. 1986. Potash fertilizers in Pakistan: Sulphate and muriate of potash. National Fertilizer Development Centre, Planning \& Development Division, Govt. of Pakistan, Islamabad. pp. 52

Department of Fertilizers, Government of India (2016) Import of Fertilizer. Available on Web: http://fert.nic.in/node/3808. access on 19th July, 2016.

Hadwani,G.J. and Gundalia, J.D. 2005. Effect of $\mathrm{N}, \mathrm{P}$ and $\mathrm{K}$ levels on yield, nutrient content, uptake and quality of summer groundnut. J. Indian Soc. Soil Sci. 53(1):125-128.

Krauss, A. and Jin Jiyun. 2000. Strategies for improving balanced fertilization. IFA Production and International Trade Conference, 17-19 October, Shanghai, China. 
Rathore,S.S. and Chaudhary, D.R.,Vaisya L.K., Shekhawat Kapila and Bhatt B.P. 2014. Schoenite and Potasium Sulphate: indigenous potassic fertilizer for rainfed groundnut (Arachis hypogea L.).Indian J. tradit. Know. 13(1):222-226.

Reddy, S.T., Reddy, D.S. and Reddy, G.P. 2011. Fertilize management for maximizing productivity and profitability of export oriented groundnut (Arachis hypogaea L.) $J$. Res. Angrau. 39(4)83-85.

Singh, A.L., and Vidya Chaudhari. 1996. Interaction of sulphur with phosphorus and potassium in groundnut nutrition in calcareous soil. Indian J. Plant Physiol. New series (1): 21-27.

Umar, S. and Moinuddin, 2002. Genotypic differences in yield and quality of groundnut as affected by potassium nutrition under erratic rainfall conditions. J. Plant Nutr., 25: 15491562.

Umar, S., Bansal, S. K., Patricia, I. and Magen, H. 1999. Effect of foliar fertilization of potassium on yield, quality, and nutrient uptake of groundnut. J. Plant Nutr. 22 (11):17851795.

Veeramani, P. and Subrahmaniyan, K. 2011. Nutrient management sustainable groundnut productivity in India - A review. Int. J. Engg. Sci. Technol. 3:8138-8147.

Vinod Kumar, B.C., Ghose, Ravibhat and Karmakar, S. 2000. Effect of irrigation and fertilizer on yield, water- use efficiency and nutrient uptake of summer groundnut. Indian J. Agron. 45(4):756-762.

\section{How to cite this article:}

Borah, B., D.S. Patil and Pawar, R.B. 2017. Enhanching Kharif Groundnut (Arachis hypogaea L.) Yield and Quality in Entisol through Potassic Fertilizer Management. Int.J.Curr.Microbiol.App.Sci. 6(11): 4068-4074. doi: https://doi.org/10.20546/ijcmas.2017.611.476 